Lesik Irina, Ph.D. (Economics), Associate Professor, Associate Professor of Economic Theory and Social Sciences Department, Mykolayiv National Agrarian University, Mykolayiv, Ukraine

ORCID ID: 0000-0003-1225-7594

e-mail: lesik@mnau.edu.ua

\title{
Assessment of Transport Infrastructure Development Level of Ukraine
}

\begin{abstract}
The purpose of the article is to create a basic model of conducting an analytical assessment of infrastructure development efficiency. The basic model allows assessing the level of current infrastructure condition which provides production and social dimension of its stable development. The article substantiates the necessity of conducting an analytical assessment of infrastructure development level which identifies its weaknesses and determines the potential of improving its performance indicators. Integral estimation of road infrastructure efficiency is proposed. To assess the problems of infrastructure development provision the comparative analyses within the proposed model are made as well as with the Data envelopment analysis (DEA) method. The results of the research allow discovering the causes of harmful phenomena in the system of management and development, identifying major trends and prospects of development.
\end{abstract}

Keywords: transport infrastructure; development; efficiency; integral assessment; comparative analyses; DEA.

\section{Удк 656.13}

Лесік I. М., кандидат економічних наук, доцент, доцент кафедри економічної теорії і суспільних наук, Миколаївський національний аграрний університет, Миколаїв, Україна

\section{Оцінка рівня розвитку транспортної інфраструктури України}

Анотація. Підвищення ролі інфраструктури в інтенсивному розвитку світової економіки пов'язане зі збільшенням споживчого попиту на якісне транспортне сполучення. Розвиток транспортної інфраструктури сприяє торговельно-економічним відносинам, утворюючи канали виробничих комунікацій та соціальної мобільності як передумови до зростання рівня життя та добробуту, тому надзвичайно важливо виявити недоліки та запропонувати конструктивні рішення, які сприятимуть ефективному розвитку рівня транспортної інфраструктури, враховуючи наявні можливості. Метою дослідження є створення базової моделі для проведення аналітичної оцінки рівня розвитку транспортної інфраструктури, яка дозволяє визначити ї̈ поточний стан, відстежити напрями формування виробничого та соціального виміру стабільності регіонів України. Обгрунтовано необхідність проведення аналітичної оцінки рівня розвитку транспортної інфраструктури. Проведено аналіз останніх досліджень та публікацій, який демонструє плюралізм думок щодо методології проведення оцінки показників розвитку та водночас одностайність у необхідності забезпечення якісного рівня інфраструктури як передумову сталого розвитку. Визначено якісні та кількісні показники розвитку транспортної інфраструктури за даними 24 регіонів країни за допомогою моделі інтегральної оцінки. Проведено порівняльний аналіз розвитку інфраструктури в рамках запропонованої інтегральної моделі та аналіз з використанням методу Data envelopment analysis (DEA), який виявив розбіжності, що свідчить про варіативність методів оцінки. Результати дослідження дозволили виявити негативні тенденції, а також визначити перспективи розвитку транспортної інфраструктури, які мають бути спрямовані на активізацію залучення у сферу матеріального виробництва окремих регіонів, тим самим збільшуючи територіальну мобільність виробничих факторів, ефективність організації економічного простору та перспективне здійснення внутрішньо територіального поділу праці, забезпечення належних умов життя людей. аналіз; DEA.

Ключові слова: транспортна інфраструктура; розвиток; ефективність; інтегральна оцінка; порівняльний

Formulation of the problem. An excellent infrastructure level provides equally high opportunities both at the regional level and in the country as a whole. For many countries, transport infrastructure is one of the main sources of budget filling, so it should be given high priority. For Ukraine, which is in a very favorable geographical location, an appropriate level of transport infrastructure could play the same role in the country's economy as ports in Singapore. Assessment of the current state of the transport infrastructure of Ukraine will determine its potential and indicate its shortcomings.
Analysis of recent research and publications. The authors believe that having efficient and effective transport infrastructure (e.g. bridges, roads, railways, airways, and tunnels) in place is essential for supporting the economic and social well-being of an economy. Delivering, managing, and maintaining transport assets that are resilient and adaptive to changing environmental conditions have become a priority for many governments worldwide [1].

To support trade, stimulate economic growth, create jobs and conditions favorable to the economic situation to prosperity, Europe needs a well-developed transport

Стаття надійшла до редакції: 18.10 .2020

Received: 18 October 2020 
network. Transport is the basis of the European integration process and is closely related to the creation of the internal market, which promotes employment and economic growth [2].

The paper Marzieh Reisi et al. highlights the role of spatial data infrastructures in decision support systems for uncertainty analysis and promoting smart cities and resilient environments [3].

Yang, L. et al. believe that it is necessary to examine the mechanism and conflicts of the complex transport, spaces, and humans system, to choose suitable strategies to design, and to critically assess the alternative plans for the sake of making sensible decisions [4].

The authors in their study seek to gain a better understanding of the interplay of transport pricing, transport service provision, cost recovery, together with explicit consideration of equity in a unified fashion. To do so, they carry out a simulation analysis, as theoretical results in second-best contexts are not clean and depend on assumptions on relevant parameters [5].

The vulnerability analysis of infrastructure exposed to natural hazards has become a key area of research due to the critical role that infrastructure plays for society and this topic has been the subject of significant advances from new data and insights following recent disasters. Transport systems, in particular, are highly vulnerable to natural hazards, and the physical damage of transport assets may cause significant disruption and socioeconomic impact [6].

Features of the socio-economic state depend on the basic characteristics of the country at the time of assessment, and the stage of its development. For Ukraine, the already existing asymmetry is an inhibiting factor, a characteristic feature of which is a different level of well-being, with the country's remoteness from assessment criteria, standards, and world average values, hyperbolized by the post-crisis state of the country [7].

Rapid response to the changeability of external factors is possible if independent infrastructure industries capable of their complex interrelationship to provide sustainable economic development of both particular regions and the whole country are available [8].

Formulation of research goals. The study's primary goal is to conduct the comparative analyses of road infrastructure objects by the method of integral assessment using of which will establish the basic model of sustainable infrastructure development's analytical assessment. The attainment of this goal determines the solution of the following issues:

- justification for the comparative analyses of infrastructure development as one of the problematic aspects and identifying competitive advantages of infrastructure in Ukraine;

- application of the method of integral assessment in determining qualitative indicators;

- application of the basic mode to map out trends and prospects of sustainable infrastructure development.

Outline of the main research material. A method of integral assessment created by Sazykin V. L. is considered for the best possible estimate of the comparable points [9]. This makes it possible not only to identify the best one in the group but also to estimate more accurate rating for each point.

The experts use various indicators that could cluster by certain criteria for analytical assessment of the infrastructure development level. The exclusivity of the assessment of transport infrastructure is that it analyzes diverse and interrelated indicators simultaneously. The basic model, in turn, reflects economic and social indicators. Applying the model of integral assessment is aimed at similar points.

Let's apply the method of integral assessment that allows a more accurate assessment of the best one among the compared objects on the example of road infrastructure.

Let's form the group of points serving as input data for further calculations (table 1).

Table $1 \mathrm{~A}$ system of indicators reflecting the level of the road infrastructure development

\begin{tabular}{|c|l|}
\hline Indicator & \multicolumn{1}{c|}{ Comparative review } \\
\hline$P_{1}$ & Gas stations, un. \\
\hline$P_{2}$ & The length of public roads, thousand $\mathrm{km}$ \\
\hline$P_{3}$ & Road haulage, million ton-kilometres \\
\hline$P_{4}$ & Cargo transportation, million ton \\
\hline$P_{5}$ & Carriage of passengers by road transport (buses) inter-city, thousand \\
\hline$P_{6}$ & Carriage of passengers by road transport (buses) international lines, thousand \\
\hline
\end{tabular}

Source: compiled by author

It should be noted that data from 24 regions of Ukraine were used for comparative analyses of road infrastructure indicators (table 2). 
Електронне наукове фахове видання з економічних наук "Modern Economics», №23 (2020), 95-101 https://modecon.mnau.edu.ua | ISSN 2521-6392

Table 2 Objects for comparative analyses of road infrastructure indicators

\begin{tabular}{|l|l|l|l|}
\hline No & \multicolumn{1}{|c|}{ Regions } & No & \\
\hline$R_{1}$ & Vinnytsia region & $R_{13}$ & Mykolaiv region \\
\hline$R_{2}$ & Volyn region & $R_{14}$ & Odesa region \\
\hline$R_{3}$ & Dnipro region & $R_{15}$ & Poltava region \\
\hline$R_{4}$ & Donetsk region & $R_{16}$ & Rivne region \\
\hline$R_{5}$ & Zhytomyr region & $R_{17}$ & Sumy region \\
\hline$R_{6}$ & Zakarpattia region & $R_{18}$ & Ternopil region \\
\hline$R_{7}$ & Zaporizhzhia region & $R_{19}$ & Kharkiv region \\
\hline$R_{8}$ & Ivano-Frankivsk region & $R_{20}$ & Kherson region \\
\hline$R_{9}$ & Kyiv region & $R_{2}$ & Khmelnytskyi region \\
\hline$R_{10}$ & Kirovohrad region & $R_{22}$ & Cherkasy region \\
\hline$R_{11}$ & Luhansk region & $R_{23}$ & Chernivtsi region \\
\hline$R_{12}$ & Lviv region & $R_{24}$ & Chernihiv region \\
\hline
\end{tabular}

Source: compiled by author

After forming the group of objects and the group of indicators that would be used for comparison, let's fill in the table of absolute deviations with the value of indicators necessary for the calculation. Since we chose the value reflecting the highest possible level for comparison, the unit of measurement called 'an average reference value' was introduced. It was obtained by dividing the indicator in Ukraine on the whole by the number of the regions researched, with the deletion of other segmentation (Table 3).

Table 3 Absolute deviation of the logical group indicators from an average reference value (Ma), of road infrastructure in Ukraine

\begin{tabular}{|c|c|c|c|c|c|c|}
\hline \multirow{2}{*}{ Regions } & \multicolumn{6}{|c|}{ Indicator } \\
\hline & $P_{1}$ & $P_{2}$ & $P_{3}$ & $\mathrm{P}_{4}$ & $P_{5}$ & $\mathrm{P}_{6}$ \\
\hline $\mathrm{R}_{1}$ & 35,75 & 2,40 & $-1219,80$ & $-21,03$ & 2160,26 & $-77,05$ \\
\hline $\mathrm{R}_{2}$ & $-101,25$ & $-0,80$ & $-232,55$ & $-36,83$ & 4486,36 & 80,25 \\
\hline $\mathrm{R}_{3}$ & 200,75 & 2,60 & 2135,15 & 274,17 & 2019,86 & $-78,25$ \\
\hline $\mathrm{R}_{4}$ & $-43,25$ & 1,50 & $-877,25$ & 62,47 & $-2238,34$ & $-40,85$ \\
\hline$R_{5}$ & $-41,25$ & 1,80 & $-1885,2$ & $-6,93$ & 216,46 & $-72,75$ \\
\hline $\mathrm{R}_{6}$ & $-30,25$ & $-3,20$ & 2070,25 & $-41,43$ & $-2494,84$ & 6,75 \\
\hline $\mathrm{R}_{7}$ & 19,75 & 0,20 & $-1503,30$ & $-19,53$ & $-947,94$ & $-86,95$ \\
\hline $\mathrm{R}_{8}$ & $-96,25$ & $-2,50$ & $-1516,50$ & $-38,23$ & 275,06 & 55,95 \\
\hline $\mathrm{R}_{9}$ & 192,75 & 2,00 & 3346,35 & 6,07 & 3396,86 & $-83,05$ \\
\hline $\mathrm{R}_{10}$ & $-77,25$ & $-0,40$ & $-1420,80$ & $-1,03$ & $-3300,84$ & $-97,95$ \\
\hline $\mathrm{R}_{11}$ & $-175,25$ & $-2,20$ & $-2520,40$ & $-45,53$ & $-4266,44$ & $-43,05$ \\
\hline$R_{12}$ & 101,75 & 1,60 & 2314,75 & $-24,43$ & 8357,86 & 306,75 \\
\hline$R_{13}$ & $-25,25$ & $-1,80$ & $-1346,10$ & $-28,93$ & $-1554,74$ & $-71,55$ \\
\hline $\mathrm{R}_{14}$ & 133,75 & 1,50 & 825,95 & $-21,23$ & 2055,26 & 13,75 \\
\hline $\mathrm{R}_{15}$ & 22,75 & 2,30 & $-270,05$ & 121,57 & $-2491,84$ & $-79,35$ \\
\hline $\mathrm{R}_{16}$ & $-97,25$ & $-1,50$ & $-848,05$ & $-33,13$ & 3377,46 & $-37,35$ \\
\hline $\mathrm{R}_{17}$ & $-112,25$ & 0,20 & $-2112,60$ & $-37,53$ & $-2013,94$ & $-92,65$ \\
\hline $\mathrm{R}_{18}$ & $-84,25$ & $-1,60$ & $-1621,80$ & $-31,83$ & 1213,76 & $-64,45$ \\
\hline $\mathrm{R}_{19}$ & 232,75 & 2,80 & 1551,050 & $-17,43$ & $-532,94$ & 102,65 \\
\hline $\mathrm{R}_{20}$ & $-61,25$ & $-1,60$ & $-1631,90$ & $-36,23$ & $-1054,04$ & $-94,65$ \\
\hline$R_{21}$ & $-30,25$ & 0,50 & $-899,85$ & $-16,73$ & $-762,84$ & $-93,05$ \\
\hline$R_{22}$ & $-17,25$ & $-0,60$ & 478,05 & $-7,53$ & $-2270,24$ & $-97,95$ \\
\hline $\mathrm{R}_{23}$ & $-92,25$ & $-3,70$ & $-1577,40$ & $-43,23$ & $-2749,24$ & $-55,85$ \\
\hline $\mathrm{R}_{24}$ & $-91,25$ & 0,60 & $-1730,60$ & $-38,33$ & $-2692,94$ & $-29,35$ \\
\hline $\mathrm{Ma}$ & 270,25 & 6,60 & 3002,85 & 50,23 & 4977,34 & 97,95 \\
\hline
\end{tabular}

Source: calculated by author based on State Statistics of Ukraine [10]

The next stage of our calculation is to find the deviation of the comparative values from the average reference value, in percentage, in consideration of the sign, the value obtained on a formula:

$$
R i=\frac{M a-P i}{M a} * 100,
$$

where $\mathrm{Ri}$ - the deviation when compared the average reference value to a selected indicator, in percentage;

$\mathrm{Ma}$ - an average benchmark; 
$\mathrm{Pi}$ - the value of an individual indicator.

In doing so, the calculated by us indicator Ma reflects the value of the highest level (the average reference value).

As there are indicators whose value is "less equal best" (for example, the number of accidents) for a particular group of objects considered while researching the road infrastructure, the formula would be as follows:

$$
R_{i}=\frac{P i-M a}{M a} * 100,
$$

After all values Ri was found, let's calculate the outcome indicator - the object's rating ${ }^{\circledR}$, on a formula:

$$
R=\frac{1}{n} \sum_{i=1}^{n} R i
$$

where $\mathrm{n}-$ is the number of objects in the group.

If the indicators in the group are not considered to be equal it is necessary to use the formula which has the form:

$$
R=\sum_{i=1}^{n} R i * V i,
$$

where $\mathrm{Vi}$ is the normed values of all indicators, thus the sum of all values is 1 .

After a comparison of the values obtained, we have the deviation from the average reference value, as a result of improvement or deterioration for each object (table 4).

\begin{tabular}{|c|c|c|c|c|c|c|c|c|}
\hline \multirow[t]{2}{*}{ Regions } & \multicolumn{5}{|c|}{ The name of the criterion } & \multirow[b]{2}{*}{ P6 } & \multirow{2}{*}{$\begin{array}{c}\text { The algebraic sum } \\
\text { of standardized } \\
\text { deviations }\end{array}$} & \multirow[t]{2}{*}{ Benchmark } \\
\hline & P1 & P2 & P3 & P4 & P5 & & & \\
\hline R1 & 13,2 & 36,3 & $-40,6$ & $-41,9$ & 43,4 & $-78,7$ & $-68,2$ & $-11,4$ \\
\hline r2 & $-37,5$ & $-12,1$ & $-7,7$ & $-73,3$ & 90,1 & 81,9 & 41,4 & 6,9 \\
\hline R3 & 74,3 & 39,4 & 71,1 & 545,8 & 40,6 & $-79,9$ & 691,3 & 115,2 \\
\hline R4 & $-16,0$ & 22,7 & $-29,2$ & 124,4 & $-45,0$ & $-41,7$ & 15,2 & 2,5 \\
\hline R5 & $-15,3$ & 27,3 & $-62,8$ & $-13,8$ & 4,3 & $-74,3$ & $-134,5$ & $-22,4$ \\
\hline R6 & $-11,2$ & $-48,5$ & 68,9 & $-82,5$ & $-50,1$ & 6,9 & $-116,4$ & $-19,4$ \\
\hline R7 & 7,3 & 3,0 & $-50,1$ & $-38,9$ & $-19,0$ & $-88,8$ & $-186,4$ & $-31,1$ \\
\hline r8 & $-35,6$ & $-37,9$ & $-50,5$ & $-76,1$ & 5,5 & 57,1 & $-137,4$ & $-22,9$ \\
\hline r9 & 71,3 & 30,3 & 111,4 & 12,1 & 68,2 & $-84,8$ & 208,6 & 34,8 \\
\hline R10 & $-28,6$ & $-6,1$ & $-47,3$ & $-2,1$ & $-66,3$ & $-100,0$ & $-250,3$ & $-41,7$ \\
\hline R11 & $-64,8$ & $-33,3$ & $-83,9$ & $-90,6$ & $-85,7$ & $-43,9$ & $-402,4$ & $-67,1$ \\
\hline R12 & 37,7 & 24,2 & 77,1 & $-48,6$ & 167,9 & 313,2 & 571,4 & 95,2 \\
\hline R13 & $-9,3$ & $-27,3$ & $-44,8$ & $-57,6$ & $-31,2$ & $-73,0$ & $-243,3$ & $-40,6$ \\
\hline R14 & 49,5 & 22,7 & 27,5 & $-42,3$ & 41,3 & 14,0 & 112,8 & 18,8 \\
\hline r15 & 8,4 & 34,8 & $-9,0$ & 242,0 & $-50,1$ & $-81,0$ & 145,2 & 24,2 \\
\hline R16 & $-36,0$ & $-22,7$ & $-28,2$ & $-66,0$ & 67,9 & $-38,1$ & $-123,2$ & $-20,5$ \\
\hline R17 & $-41,5$ & 3,0 & $-70,4$ & $-74,7$ & $-40,5$ & $-94,6$ & $-318,6$ & $-53,1$ \\
\hline R18 & $-31,2$ & $-24,2$ & $-54,0$ & $-63,4$ & 24,4 & $-65,8$ & $-214,2$ & $-35,7$ \\
\hline R19 & 86,1 & 42,4 & 51,7 & $-34,7$ & $-10,7$ & 104,8 & 239,6 & 39,9 \\
\hline R20 & $-22,7$ & $-24,2$ & $-54,3$ & $-72,1$ & $-21,2$ & $-96,6$ & $-291,2$ & $-48,5$ \\
\hline R21 & $-11,2$ & 7,6 & $-30,0$ & $-33,3$ & $-15,3$ & $-95,0$ & $-177,2$ & $-29,5$ \\
\hline R22 & $-6,4$ & $-9,1$ & 15,9 & $-15,0$ & $-45,6$ & $-100,0$ & $-160,2$ & $-26,7$ \\
\hline R23 & $-34,1$ & $-56,0$ & $-52,5$ & $-86,1$ & $-55,2$ & $-57,0$ & $-341,0$ & $-56,8$ \\
\hline R24 & $-33,8$ & 9,1 & $-57,6$ & $-76,3$ & $-54,1$ & $-30,0$ & $-242,69$ & $-40,5$ \\
\hline $\mathrm{Ma}$ & 270,3 & 6,6 & 3002,8 & 50,2 & 4977,3 & 98,0 & $x$ & $x$ \\
\hline
\end{tabular}

Table 4 Standardized deviations of indicators' values from the average reference value of the objects' ratings (Ma) of the road infrastructure in Ukraine, \%

Source: compiled by author

The deviations are calculated to fulfill the function of standardization (rationing), since the calculations may use indicators different in meaning (intensive, extensive, absolute, and others). The algebraic sum of standardized deviations calculated for each object is the overall rating for this object. It characterizes to what percent the object deviates from the average, noting that the rating of the object for comparison is zero. The overall rating in the result of division into the number of the indicators makes it possible to calculate the average reference rating for each object.

Let's form a discrete vibrational range using the data obtained.

To that end, let's sort the range in ascending order (table 5). 
Електронне наукове фахове видання з економічних наук "Modern Economics», №23 (2020), 95-101 https://modecon.mnau.edu.ua | ISSN 2521-6392

Table 5 The calculation of the central points of analytical assessment of the road infrastructure efficiency in Ukraine

\begin{tabular}{|c|c|c|}
\hline$x$ & $|x-x j|$ & $\left(x-x j^{2}\right)$ \\
\hline-67.07 & 57.47 & 3303.33 \\
\hline-56.83 & 47.23 & 2231.11 \\
\hline-53.1 & 43.5 & 1892.65 \\
\hline-48.53 & 38.93 & 1515.9 \\
\hline-41.72 & 32.12 & 1031.99 \\
\hline-40.55 & 30.95 & 958.19 \\
\hline-40.45 & 30.85 & 952.01 \\
\hline-35.7 & 26.1 & 681.45 \\
\hline-31.07 & 21.47 & 461.16 \\
\hline-29.54 & 19.94 & 397.79 \\
\hline-26.69 & 17.09 & 292.22 \\
\hline-22.91 & 13.31 & 177.28 \\
\hline-22.42 & 12.82 & 164.47 \\
\hline-20.53 & 10.93 & 119.57 \\
\hline-19.4 & 9.8 & 96.13 \\
\hline-11.36 & 1.76 & 3.11 \\
\hline 2.53 & 12.13 & 147.03 \\
\hline 6.9 & 16.5 & 272.1 \\
\hline 18.8 & 28.4 & 806.3 \\
\hline 24.2 & 33.8 & 1142.13 \\
\hline 34.77 & 44.37 & 1968.29 \\
\hline 39.93 & 49.53 & 2452.77 \\
\hline 95.23 & 104.83 & 10988.37 \\
\hline 115.22 & 124.82 & 15578.89 \\
\hline-230.29 & 828.69 & 47634.21 \\
\hline
\end{tabular}

Source: compiled by author

Let's find out the indicators of the distribution center to assess the rage of distribution:

$$
\bar{x}=\frac{\sum x_{i}+f_{i}}{\sum f_{i}},
$$

Mode as the most common value of the sign of these data items, where $x 0$ - is the beginning of the modal interval; $h$ - is the value of the interval; $f 2$ is the frequency respective to the modal interval; $f 1$ is the pre-modal frequency; $f 3$ is the after-modal frequency:

$$
M_{o}=x_{0}+h \frac{f_{2}-f_{1}}{\left(f_{2}-f_{1}\right)+\left(f_{2}-f_{3}\right)},
$$

The median divides the sample into two parts: one half is the variant less than the median, the other one is more. Let's calculate the median (Me) as the value of the sign for the middle of the ranked (structured) data:

$$
M_{e}=x_{0}+i+\frac{\frac{\sum f_{i}}{2}-S_{m-1}}{f_{m}},
$$

Where Me is the required median; $x 0$ is the lower limit of the interval, which contains the median; $h$ - is the value of the interval; $\Sigma \mathrm{fi}$ is the sum of the frequencies or the number of members; Sm-1 is the sum of the accumulated intervals' frequencies before the median; $f m$ is the frequency of the median interval.
Let's calculate the width of the variation as the difference between the maximum and minimum value of the primary data $\mathrm{R}=\mathrm{Xmax}-\mathrm{Xmin}$

To take into account the differences in all these data items, let's calculate the average linear deviation.

$$
d=\frac{\sum\left|x_{i}-\bar{x}\right| * f_{i}}{\sum f_{i}}
$$

Using dispersion, we characterize the limits of spread about its mean:

$$
D=\frac{\sum\left(x_{i}-\bar{x}\right)^{2} * F_{i}}{\sum f_{i}}
$$

The calculations made gives the following results: the weighted average is 9,6; the mode is absent as there are several indicators with the same value; the range comprises the even number of units, thus the median is identified as an average from two central values -22,6; the width of the variation is 182,3 ; the average linear deviation is 34,53 . Each value of the range differs from the other one by 34,5 on average; the dispersion is 1984,8 ; the average quadratic is 44,5 , so each value of the range differs from the average value- 9,6 by 44,5 on average.

The analytical assessment of the researched objects of the road infrastructure in 24 regions of Ukraine illustrates the level of distribution of the sustainable development centers. Thus, by the results of the calculations Dnipro 
region, Lviv region, Kharkiv region, Kyiv region, Poltava region have entered the rating of Top-5 regions formed by us. They have the positive largest from the average reference value (table 6).

Table 6 Top -5 regions leaders and outsider by the level of development of the road infrastructure in Ukraine

\begin{tabular}{|c|c|c|c|}
\hline Rating & Regions of Ukraine & Anti rating & Regions of Ukraine \\
\hline 1 & Dnipro region & 1 & Lugansk region \\
\hline 2 & Lviv region & 2 & Chernivtsi region \\
\hline 3 & Kharkiv region & 3 & Sumy region \\
\hline 4 & Kyiv region & 4 & Kherson region \\
\hline 5 & Poltava region & 5 & Kirovograd region \\
\hline
\end{tabular}

Source: compiled by author

The leader of our rating is the Dnipro region, which claims to be the economic locomotive of Ukraine. The region has strong industrial and economic potential, high population rate which has caused the development of different types of transport communication. Lviv region is also the center of industrial and agricultural development. It is one of the most densely populated in Ukraine, has its recreation zones, borders on the Republic of Poland in the west. Kharkiv region and Poltava region also differ by the level of economic development and border on the Dnipro region on the north. Kyiv region is a large center of the development of industrial, economic, scientific progress with the administrative unit in the city of national importance, which is Kyiv (the capital of Ukraine).

The anti-rating is headed by the Lugansk region, which is located on the territory of the military actions since 2014. All the regions from the anti-rating have the same negative features, like narrow specialization or orientation of industry on imported raw materials; outdated technologies; dangerous production, and low demand as a result. The transport communication contains transit routes, unlike the top- 5 leaders with the routes of national and international importance.

Subsequently, the methodology for applying (DEA) model may also be used to compare the level of development of several infrastructure industries to identify the most promising ones and to form the strategic objectives for sustainable development. In our study [8] the method of Data envelopment analysis (DEA) allowed a more accurate assessment of the best one among the compared objects on the example of road infrastructure. The analytical assessment of the researched objects of the road infrastructure in 24 regions of Ukraine by the method of Data envelopment analysis illustrates the level of distribution of the sustainable development centers (table 7).

Table 7 Top regions leaders and outsider by the level of development of the road infrastructure in Ukraine CRS

\begin{tabular}{|l|c|c|}
\hline \multirow{2}{*}{ Rating } & \multicolumn{2}{c|}{ Regions of Ukraine } \\
\cline { 2 - 3 } & max Technical Efficiency CRS & min Technical Efficiency CRS \\
\hline Road haulage & Zakarpattia region & Luhansk region \\
\hline Cargo transportation & Dnipro region & Luhansk region \\
\hline $\begin{array}{l}\text { Carriage of passengers by road } \\
\text { transport (buses) inter- city }\end{array}$ & Rivne region & Cherkasy region \\
\hline $\begin{array}{l}\text { Carriage of passengers by road } \\
\text { transport (buses) international lines }\end{array}$ & Lviv region & Cunsk \\
\hline
\end{tabular}

Source: compiled by author based on [8]

Thus, by the results of the calculations Zakarpattia region, Dnipro region, Rivne region, Lviv region have entered the rating of max TECRS regions formed by us those have the positive largest.

Despite the presence of the negative indicators which put regions into anti-rating, each of them has its features. At the same time with the critical assessment, the result may become the base for detecting the regions ready to develop towards unlocking its potential: recreation activities, green tourism, organic production, green energetics. Transport communication as a strategically necessary component able to provide a high level of development in any of the potential areas. As to ensure our conclusions, the Trans-European Transport Network
(TEN-T) policy addresses the implementation and development of a Europe-wide network of railway lines, roads, inland waterways, maritime shipping routes, ports, airports, and railroad terminals. The ultimate objective is to close gaps, remove bottlenecks and technical barriers, as well as to strengthen social, economic, and territorial cohesion in the EU. Besides the construction of new physical infrastructure, the TEN-T policy supports the application of innovation, new technologies, and digital solutions to all modes of transport. The objective is improved use of infrastructure, reduced environmental impact of transport, enhanced energy efficiency, and increased safety [11]. 
Conclusions. Thus, the proposed basic model has allowed allows assessing the level of current infrastructure condition, identifying the causes of negative phenomena in a region, indicating the activities to prevent them. The practical value of the research is that the given basic model can be used for analytical assessment of separate indicators and the groups of indicators but also the region as a whole. The use of the integral assessment method in identifying qualitative indicators allows further detailed indicators; their modification influences the total level of the object development. Only one element of the system of infrastructure provision was considered, which except road infrastructure also includes railway, air, river and sea transport, utilities infrastructure, electricity and water supply, information infrastructure (mobile communication and internet). To make strategic decisions it is necessary to conduct a complex assessment of all the above elements. This proves the relevance of the topic and defines the direction of our further researches.

Research is a conscious and directed effort to increase understanding and discover new and better ways to achieve goals. The implementation of innovation in an industry is determined by factors that accumulate internal and external capabilities. In turn, investments are considered to be the most important tool for creating conditions for economic development countries.

\section{References:}

1. Liu, H. J., Love, P. E., Sing, M. C., Niu, B., \& Zhao, J. (2019). Conceptual framework of life-cycle performance measurement: Ensuring the resilience of transport infrastructure assets. Transportation Research Part D: Transport and Environment, 77, 615-626.

2. Kopiec, A. C., Siguencia, L. O., Szostak, Z. G., \& Marzano, G. (2019). Transport infrastructures expenditures and costs analysis: the case of Poland. Procedia Computer Science, 149, 508-514.

3. Reisi, M., Sabri, S., Agunbiade, M., Rajabifard, A., Chen, Y., Kalantari, M., ... \& Li, Y. (2020). Transport Sustainability Indicators for an Enhanced Urban Analytics Data Infrastructure. Sustainable Cities and Society, 102095.

4. Yang, L., van Dam, K. H., Majumdar, A., Anvari, B., Ochieng, W. Y., \& Zhang, L. (2019). Integrated design of transport infrastructure and public spaces considering human behavior: A review of state-of-the-art methods and tools. Frontiers of Architectural Research, 8(4), 429-453.

5. Pavón, N., \& Rizzi, L. I. (2019). Road infrastructure and public bus transport service provision under different funding schemes: A simulation analysis. Transportation Research Part A: Policy and Practice, 125, 89-105.

6. Argyroudis, S. A., Mitoulis, S. A., Winter, M. G., \& Kaynia, A. M. (2019). Fragility of transport assets exposed to multiple hazards: State-of-theart review toward infrastructural resilience. Reliability Engineering \& System Safety, 191, 106567.

7. Lesik, I. M. (2018). Socio-economic aspects of society development. Ukrainian Black Sea region agrarian science. (4), 11-17. DOI: 10.31521/2313-092X/2018-4(100)-2.

8. Lesik, I., et al. (2020). Assessment of management efficiency and infrastructure development of Ukraine. Management Science Letters. 10(13) 3071-3080.

9. Sazykin, V.L. (2004). A new method of integral assessment. Bulletin of the Orenburg State University (12).

10. State Statistics Committee of Ukraine. 2019. Transport and Communication of Ukraine - 2018. Kyiv: State Statistics Service of Ukraine.

11. EP, C. (2013). Regulation (EU) No 1315/2013 of the European Parliament and of the Council of 11 December 2013 on Union guidelines for the development of the trans-European transport network and repealing Decision No 661/2010/EU. Official Journal of the European Union, 1-128.

12. Lemer, A. C., Chong, K. P., \& Tumay, M. T. (1995). Research as A Means for Improving Infrastructure. Journal of Infrastructure Systems, 7(1), 615.

13. Lesik, I. M. (2016). Formation and functioning of the vegetable products' market is on innovative principles. Economics, management, law: innovation strategy: Collection of scientific articles. Henan Science and Technology Press, Zhengzhou, China. P. 29-31. 